\title{
Fluid balance and mortality in critically ILL patients
}

\author{
Y Ben Aicha*, A Ben Souissi, S Kamoun, S Koubaji, F Haddad, MS Mebazaa \\ From ESICM LIVES 2015 \\ Berlin, Germany. 3-7 October 2015
}

\section{Introduction}

Intravenous fluids are widely administrated to correct intravascular volume deficit or acute hypovolemia. However, generalized endothelial injury and capillary leak is a common condition in critically ill patients. In such a state, overzealous fluid therapy results in extravascular movement of water, electrolytes and proteins leading to tissue edema and organ dysfunction. The aim of this study is to assess whether positive fluid balance is associated with worse outcomes and increased mortality in critically ill patients.

\section{Methods}

This was a retrospective study. All patients admitted between 1 July and 31 December 2014 were eligible for the study, except those who stayed in the ICU for less than 48 hours. We collected data on demographics, comorbidity conditions, APACHE II and SAPSII scores. Acute kidney injury was classified using the worst RIFLE score obtained during the first 7 days and the need of renal replacement therapy. Vasopressors use, ICU mortality, hospital lengths of stay and mechanical ventilation were also registered. The fluid balances were calculated at the second, 7, 14, 21 day and at the hospital discharge.

\section{Results}

A total of 95 patients were included to the cohort study. Septic shock represented $66 \%$ of the cases. Median age was $53 \pm 19$ years old. $64 \%$ were men. The mean APACHE II score was $20 \pm 7$, and the mean SAPSII score was $46 \pm 18$. The mortality rate was $37.5 \%$.

We examined cumulative fluid balance among patients who died and those that survived (table1).

To evaluate the relationship between cumulative fluid balance and outcome we stratified our study population into 4 groups based upon their cumulative balances observed on hospital discharge: less than zero $(n=2)$,

Mongi Slim University Hospital La Marsa, Anesthesiology and ICU Department, Sidi Daoued, Tunisia
Table 1. Cumulative fluid balance $(\mathrm{mL})$

\begin{tabular}{llll}
\hline & $\begin{array}{l}\text { Survivors } \\
(\mathbf{n}=\mathbf{5 6})\end{array}$ & $\begin{array}{l}\text { Non-Survivors } \\
(\mathbf{n}=\mathbf{3 9})\end{array}$ & $\begin{array}{l}\mathbf{p} \\
\text { value }\end{array}$ \\
\hline Day 2 & $2120 \pm 1670$ & $2839 \pm 1235$ & 0.023 \\
\hline Day 7 & $5763 \pm 2311$ & $6947 \pm 3005$ & 0.019 \\
\hline Day 14 & $4024 \pm 1986$ & $4673 \pm 2265$ & 0.031 \\
\hline Day 21 & $4542 \pm 2567$ & $7243 \pm 3480$ & 0.023 \\
\hline Total fluid balance & $5882 \pm 3887$ & $10949 \pm 4564$ & 0.019 \\
\hline
\end{tabular}

1 to $5 \mathrm{~L}$ positive balance $(\mathrm{n}=5), 5$ to $10 \mathrm{~L}$ positive balance $(\mathrm{n}=13)$, and over $10 \mathrm{~L}$ positive balance $(\mathrm{n}=19)$. Among these 4 fluid balance groups, those who had negative or less positive fluid balance had lower mortality compared to those with the larger positive fluid balances.

The need for renal replacement therapy, and RIFLE score of 3 were more frequent among non-survivors $(\mathrm{p}<0.05)$.

Non-survivors had also significantly fewer ICU hospital days (14 days vs. 19 days $\mathrm{p}=0.045)$ and markedly more days free from mechanical ventilation ( 6 days vs. 14 days $\mathrm{p}=0.036)$. The use of vasopressors was also more prolonged among the same group $(\mathrm{p}=0.034)$.

\section{Conclusions}

Positive cumulative fluid balance is associated with significantly higher mortality and worse outcomes. Our results raise the hypothesis that a judicious fluid balance after early resuscitation might be a useful tool to improve prognosis in critically ill patients.

Published: 1 October 2015

doi:10.1186/2197-425X-3-S1-A532

Cite this article as: Ben Aicha et al:: Fluid balance and mortality in critically ILL patients. Intensive Care Medicine Experimental 2015 3(Suppl 1): A532.

\section{SpringerOpen ${ }^{\circ}$}

(c) 2015 Ben Aicha et al.; This is an Open Access article distributed under the terms of the Creative Commons Attribution License (http://creativecommons.org/licenses/by/4.0), which permits unrestricted use, distribution, and reproduction in any medium, provided the original work is properly cited. 